\title{
State of spring phytoplankton and quality of the Kenozero waters in 2018
}

\author{
NG Otchenash ${ }^{1}$, GA Dvoryankin ${ }^{2,3}$, EN Imant $^{2}$ \\ 1 Northern Branch of the Polar Research Institute of Marine Fisheries and Oceanography (Arkhangelsk, Russia) \\ 2 N. Laverov Federal Centre for Integrated Arctic Research, Russian Academy of Sciences (Arkhangelsk, Russia) \\ 3 Kenozersky National Park (Arkhangelsk, Russia)
}

Corresponding author: Natalia Otchenash (otchenasch@pinro.ru)

Academic editor: Yuliya V. Bespalaya • Received 10 June 2019 • Accepted 14 June 2019 • Published 27 June 2019

Citation: Otchenash NG , Dvoryankin GA, Imant EN (2019) State of spring phytoplankton and quality of the Kenozero waters in 2018. Arctic Environmental Research 19(1): 43-48. https://doi.org/10.3897/issn2541-8416.2019.19.1.43

\begin{abstract}
Phytoplankton constitutes a key part of all aquatic ecosystems. It produces organic matter, thus forming the first level of food chains in water bodies. In addition, phytoplankton plays a major role in the water quality formation. The studies of algocoenosis always remain relevant, since the obtained data provides important information on the ecological status of water bodies. This information can subsequently be used for planning and implementing environmental measures, which are particularly significant for water bodies located in specially protected areas. National parks existing for the purposes of nature preservation, education and research are also designed for tourism, which makes their ecosystems more vulnerable. Population residing in such territories and its economic activity may also carry some environmental risks, which necessitates regular complex observations. This paper covers the state of spring phytoplankton community of Lake Kenozero in 2018, its qualitative and quantitative characteristics (species composition, abundance and biomass). In the course of research, we identified 70 phytoplankton taxa belonging to seven divisions: Bacillariophyta, Dinophyta, Chlorophyta, Cyanophyta, Chrysophyta, Xanthophyta and Euglenophyta. The dominant species complex included diatoms (Asterionella formosa, Melosira granulata, Tabellaria fenestrata), representatives of Dinophyta (Gymnodinium sp.), as well as small euglenoids. Species diversity was estimated using the Shannon-Weaver index. Aquatic environment contamination was assessed, i.e. the saprobity index was calculated and the class of surface water quality was determined. According to the water quality classification of water bodies and watercourses by hydrobiological indicators, Lake Kenozero was assigned the second class of water quality (moderately polluted).
\end{abstract}

\section{Keywords}

Lake Kenozero, phytoplankton, abundance, biomass, surface water quality, saprobity index

Copyright Otchenash NG et al. This is an open access article distributed under the terms of the Creative Commons Attribution License (CC-BY 4.0), which permits unrestricted use, distribution, and reproduction in any medium, provided the original author and source are credited. 


\section{Introduction}

Lake Kenozero is one of the largest lakes in the Arkhangelsk Region, as well as the biggest one in the Kenozersky National Park. It has a total area of approximately $75 \mathrm{~km}^{2}$, with water surface covering 66.3 $\mathrm{km}^{2}$. Numerous islands and peninsulas divide the lake into separate stretches and bays (Fig. 1). A notable feature of the lake consists in a very complex bottom relief and close proximity of deep waters to the shores and shoals. The lake is characterized by good flowage; however, partially isolated bays and stretches of its northern and southern parts can possess their local hydrological and hydrochemical features, which sometimes differ greatly from each other (Dvoryankin 2016). Biomonitoring of algal flora allows the overall state of a water body to be controlled, along with its state in individual locations. The composition of phytoplankton community most accurately reflects the current state of biogeocoenosis, which is essential in the context of national parks. Initial studies of phytoplankton in Lake Kenozero were carried out at the end of August 2001 by an expedition from the Northern Water Problems Institute, Karelian Research Centre (Dvoryankin 2016). Subsequently, biomonitoring of algal flora was carried out two more times: in October 2009 and in June 2018 (present study). This work is aimed at characterising the phytoplankton community, as well as assessing the quality of the Kenozero waters according to hydrobiological indicators.

\section{Materials and methods}

Hydrobiological research was carried out within the programme for hydrobiological and ecological study of Lake Kenozero (Kenozersky National Park).

Samples for the quantitative and qualitative analysis of phytoplankton were taken from the surface water in a volume of 1 litre; the material was fixed with $40 \%$ formaldehyde solution. The samples were concentrated up to $1 \mathrm{ml}$ using the traditional sedimentary method (Abakumov 1992). Structural analysis of the material was performed in a laboratory using temporary preparations and a BiOptik S-300 laboratory light microscope (with magnifications of $\mathrm{X} 100$ and X400). The number of microalgae cells was counted under the entire surface of the coverslip. The cell was chosen as a counting unit. Phytoplankton abundance $(\mathrm{N})$ per unit of water volume was calculated using the following formula

$$
\mathrm{N}=\left(\frac{\mathrm{V}_{\text {conc }} \cdot \mathrm{S}}{\mathrm{a} \cdot \mathrm{V}_{\text {sub }} \cdot \mathrm{V}_{\text {in }} \cdot \mathrm{S}_{\mathrm{c}}}\right) \cdot \mathrm{n}
$$

where $S$ - total area of the coverslip; $S_{c}$ - area of the coverslip under which phytoplankton was counted; $\mathrm{n}$ - number of counted cells; $\mathrm{V}_{\text {conc }}$ - volume of the concentrated sample; $\mathrm{V}_{\text {in }}$ - initial sample volume (1 litre); $\mathrm{V}_{\text {sub }}$ - subsample volume $(0.05 \mathrm{ml})$; a - number of calculated subsamples (Frank 1988).

The Shannon-Weaver index was calculated as follows

$$
\mathrm{H}^{\prime}=-\sum p_{i} \ln p_{i}
$$

$\mathrm{H}^{\prime}$ - index; $\mathrm{p}_{\mathrm{i}}$ - proportion of individuals belonging to the $j$-th species. The true value of $p_{i}$ in samples is unknown, but is estimated as $n_{i} / \mathrm{N}$ (where $\mathrm{N}$ - abundance, ind. $/ \mathrm{m}^{3} ; \mathrm{n}_{\mathrm{i}}$ - number of individuals of one species, ind. $/ \mathrm{m}^{3}$ ).

The contamination of aquatic environment was estimated by calculating the saprobity index $S$ according to the Pantle-Buck's method modified by Sladechek using the following formula

$$
S=\frac{\sum s h}{\sum h}
$$

where S - indicator value of each species (Unified methods for the study of water quality1977a, b); h relative frequency of occurrence.

The higher the saprobity index, the higher the level of water pollution is. The saprobity indices for five classes of water quality are as follows: class I (conditionally clean) - less than 1.5; class II (moderately polluted) - from 1.5 up to 2.5; class III (polluted) from 2.5 up to 3.5 ; class IV (dirty) - from 3.5 up to 4.0; class $\mathrm{V}$ (extremely dirty) - more than 4.07 ( $\mathrm{RD}$ 52.24.309-2016). Previously, this method was successfully used on the territory of the Arkhangelsk Region to determine the water quality of the Northern Dvina in 2014 (Zmetnaya and Novikova 2015). 


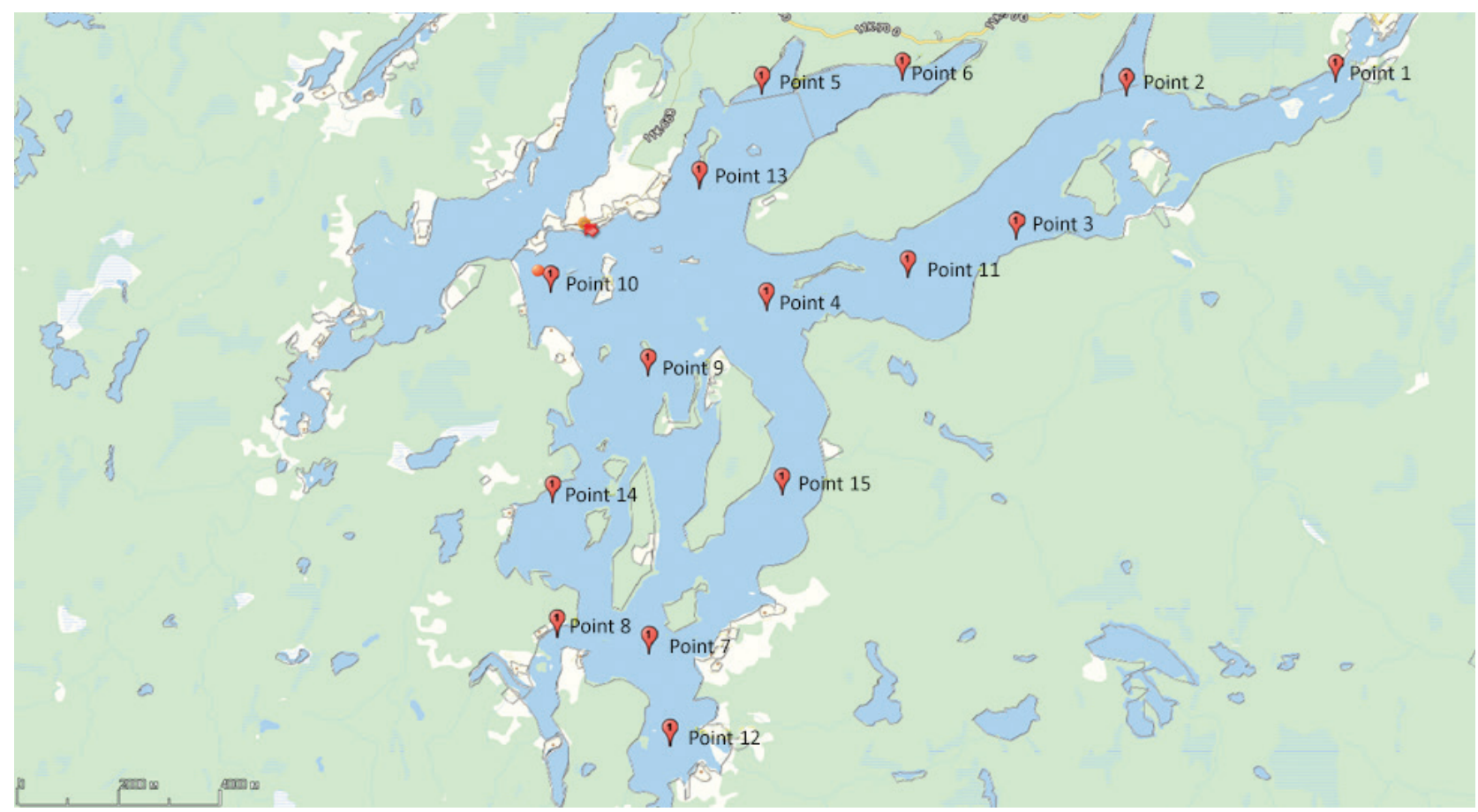

Fig. 1. Map of phytoplankton sampling sites (Kenozero, June 2018)

The composition of phytoplankton species was determined using identifiers of microalgae. The biomass was calculated using the tables for phytoplankton size and weights (mass) (Mikheeva 1999).

\section{Results}

Hydrobiological studies of phytoplankton were carried out on 13-14 June (hydrobiological spring) in the Kenozero water area. Samples were taken from the surface water at 15 points over the entire surface of the water body (Fig. 1). The analysis revealed that the phytoplankton community in Lake Kenozero was represented by microalgae belonging to seven groups: Bacillariophyta, Dinophyta, Chlorophyta, Cyanophyta, Chrysophyta, Xanthophyta and Euglenophyta. A total of 70 species and super taxa of microalgae were found. Diatoms were found to be the most diverse in terms of species composition - 50 species, which accounted for $72 \%$ of the total number of found and identified taxa (Fig. 2). Green and blue-green algae were represented by a significantly smaller number of species ( 7 and 4 species, respectively). Dinoflagellates and yellow-green algae accounted for 3 representatives each, whereas only 2 species of golden algae and 1 taxon of euglenoids were found (Gollerbakh and Polyansky 1953, Komarenko and Vasilyeva 1975, Komulaynen et al. 2006, Krishtovich 1949a, b, Kursanov 1953).

The number of identified microalgae at individual stations ranged from 14 (station 14) to 35 (station 5) averaging 22 species.

\section{Discussion}

The most common types of planktonic algae included Melosira granulata and Fragilaria crotonensis (present at all stations), as well as Tabellaria fenestrata, Gymnodinium sp., Asterionella formosa, Closterium acutum and Protoperidinium bipes, which were encountered less frequently (Table 1).

The presence of golden algae (Dinobryon), which prefer water bodies having a minimum content of inorganic phosphorus, indicates oligotrophic conditions 




Fig. 2. Taxonomic composition of phytoplankton in Lake Kenozero (June, 2018)

throughout most of the lake (Barinova et al. 2006). Most of the identified microalgae have the status of widespread species or cosmopolitans and are common representatives of lake algal flora (Komulaynen et al. 2006).

The total abundance of planktonic microalgae in Kenozero (June 2018) varied from 3,520 to 50,960 cells/L. The highest and the lowest abundances were registered at stations 3 and 15, respectively. Such a significant difference is due to the complex bottom relief and strong coastline indentation, which result in local hydrological and hydrochemical features and, consequently, variations in the phytoplankton community. The average abundance amounted to a very low value of 23750 cells/L, characteristic of oligotrophic water bodies, whose algal flora is outside the vegetation peaks (Fig. 3) In general, the level of phytoplankton abundance was very low.

The total biomass of phytoplankton organisms in the studied area varied from 8.01 to $138.56 \mu \mathrm{g} / \mathrm{L}$. The highest value of total biomass was registered at station 3 , located in the northern part of the lake, whereas station 15 showed the smallest value. The average phytoplankton biomass amounted to $47.61 \mu \mathrm{g} / \mathrm{L}$ (Fig. 4).

Representatives of Bacillariophyta (Melosira granulata, Asterionella formosa) and euglenoids, whose species could not be identified, were found to be the most numerous at all stations of the studied area. In addition, a significant number of Fragilaria, Tabellaria and Nitzschia representatives were found. At most stations, the maximum biomass was observed for representatives of Bacillariophyta (Melosira granulata, Tabellaria fenestrata), Euglenophyta and Dinophyta. It should be noted that representatives of Euglenophyta were predominant at stations 1, 2, 3 and 11. Euglenophyta grow in areas affected by organic pollution (Barinova et al. 2006).

The values of the Shannon-Weaver diversity index by phytoplankton abundance ranged from 1.9 (station 3) to 3.6 (station 12), whereas calculated by biomass it varied from 1.9 (stations 3 and 14) to 3.5 (station 6). The diversity indices by abundance and by biomass averaged 2.9 and 2.8 , respectively.

The saprobity index according to V. Sladechek ranged from 1.57 to 1.8 (station 1 ) averaging 1.6. The saprobic state of the Kenozero waters corresponded to the oligo- $\beta$-mesosaprobic conditions (saprobity index 1.5-2.5), or class II of water quality (moderate content of organic substances) (Abakumov 1992, RD 52.24.309-2016). 
Table 1. Taxonomic composition of phytoplankton in Lake Kenozero (June, 2018)

\begin{tabular}{|c|c|c|c|}
\hline Taxon & Occurrence & Taxon & Occurrence \\
\hline Bacillariophyta & & Nitzschia linearis W.Smith, 1853 & $40 \%$ \\
\hline Achnanthes sp. & $60 \%$ & Nitzschia longissima (Brébisson) Ralfs, 1861 & $40 \%$ \\
\hline Amphoracoffeaeformis (C.Agardh) Kützing, 1844 & $60 \%$ & Nitzschia palea (Kützing) W.Smith, 1856 & $27 \%$ \\
\hline Amphora exigua Gregory, 1857 & $7 \%$ & Nitzschia sigmoidea (Nitzsch) W.Smith, 1853 & $7 \%$ \\
\hline Amphora ovalis (Kützing) Kützing, 1844 & $20 \%$ & Nitzschia sp. & $7 \%$ \\
\hline Asterionella formosa Hassall, 1850 & $87 \%$ & Nitzschia subtilis (Kützing) Grunow, 1880 & $7 \%$ \\
\hline Caloneis bacillum (Grunow) Cleve, 1894 & $27 \%$ & Nitzschia tryblionella Hantzsch, 1860 & $7 \%$ \\
\hline Caloneis silicula (Ehrenberg) Cleve, 1894 & $47 \%$ & Nitzschia vermicularis (Kützing) Hantzsch, 1860 & $13 \%$ \\
\hline Caloneis sp. & $20 \%$ & Stauroneis anceps Ehrenberg, 1843 & $13 \%$ \\
\hline Cocconeis sp. & $20 \%$ & Stephanodiscus hantzschii Grunow, 1880 & $13 \%$ \\
\hline Cyclotella bodanica Eulenstein ex Grunow, 1878 & $13 \%$ & Synedra ulnasensu Hustedt, 1942 & $53 \%$ \\
\hline Cyclotella comta (Ehrenberg) Kützing, 1849 & $33 \%$ & Tabellaria fenestrata (Lyngbye) Kützing, 1844 & $93 \%$ \\
\hline Cyclotella planctonica Brunnthaler, 1901 & $47 \%$ & Chlorophyta & \\
\hline Cyclotella sp. & $13 \%$ & Ankistrodesmus convolutus Corda, 1838 & $13 \%$ \\
\hline Cymbella ventricosa (C.Agardh) C.Agardh, 1830 & $7 \%$ & Ankistrodesmus falcatus (Corda) Ralfs, 1848 & $7 \%$ \\
\hline Diatoma hiemale (Lyngb.) Heiberg, 1863 & $33 \%$ & Closterium acutum Brébisson, 1848 & $87 \%$ \\
\hline Diploneis interrupta (Kützing) Cleve, 1894 & $7 \%$ & Closterium sp. & $13 \%$ \\
\hline Diploneis ovalis (Hilse) Cleve, 1891 & $13 \%$ & Crucigenia tetrapedia (Kirchner) Kuntze, 1898 & $7 \%$ \\
\hline Eunotia pectinalis (Kützing) Rabenhorst, 1864 & $20 \%$ & Dictyosphaerium sp. & $20 \%$ \\
\hline Eunotia praerupta Ehrenberg, 1843 & $7 \%$ & Scenedesmus quadricauda (Turpin) Brébisson, 1835 & $13 \%$ \\
\hline Eunotia sp. & $40 \%$ & Chrysophyta & \\
\hline Fragilaria bicapitata Mayer, 1917 & $7 \%$ & Dinobryon spirale Iwanoff, 1899 & $73 \%$ \\
\hline Fragilaria capucina Desmazières, 1830 & $53 \%$ & Dinobryon divergens O.E.Imhof, 1887 & $60 \%$ \\
\hline Fragilaria construens (Ehrenberg) Grunow, 1862 & $7 \%$ & Mallomonas sp. & $60 \%$ \\
\hline Fragilaria crotonensis Kitton, 1869 & $100 \%$ & Cyanophyta & \\
\hline Gomphonema acuminatum Ehrenberg, 1832 & $7 \%$ & Anabaena sp. & $27 \%$ \\
\hline Gomphonema gracile Ehrenberg, 1838 & $13 \%$ & Aphanizomenon flos-aquae(Linnaeus) Ralfs ex Bornet \& & $7 \%$ \\
\hline Gyrosigma acuminatum (Kützing) Rabenhorst, 1853 & $7 \%$ & Flahault, 1888 & \\
\hline Melosira granulata (Ehrenberg) Ralfs, 1861 & $100 \%$ & Gloeocapsa sp. & $7 \%$ \\
\hline Meridion circulare (Greville) C.Agardh, 1831 & $13 \%$ & Microcystis sp. & $7 \%$ \\
\hline Navicula gastrum Lauby, 1910 & $7 \%$ & Dinophyta & \\
\hline Navicula lanceolata Ehrenberg, 1838 & $13 \%$ & Gymnodinium sp. & $93 \%$ \\
\hline Navicula mutica (Kützing) Frenguelli, 1924 & $40 \%$ & Peridinium sp. & $7 \%$ \\
\hline Navicula placentula Pantocsek, 1902 & $20 \%$ & Protoperidinium bipes (Paulsen, 1904) Balech, 1974 & $80 \%$ \\
\hline Navicula sp. & $20 \%$ & Euglenophyta & \\
\hline Navicula tuscula Pantocsek, 1902 & $40 \%$ & Euglena sp. & $33 \%$ \\
\hline Nitzschia acuminata (W.Smith) Grunow, 1880 & $7 \%$ & Xanthophyta & \\
\hline Nitzschia gracilis Brébisson ex H.L. Smith, 1874-1879 & $27 \%$ & Centritractus sp. & $40 \%$ \\
\hline Nitzschia holsatica Hustedt, 1930 & $53 \%$ & Tribonema sp. & $7 \%$ \\
\hline
\end{tabular}

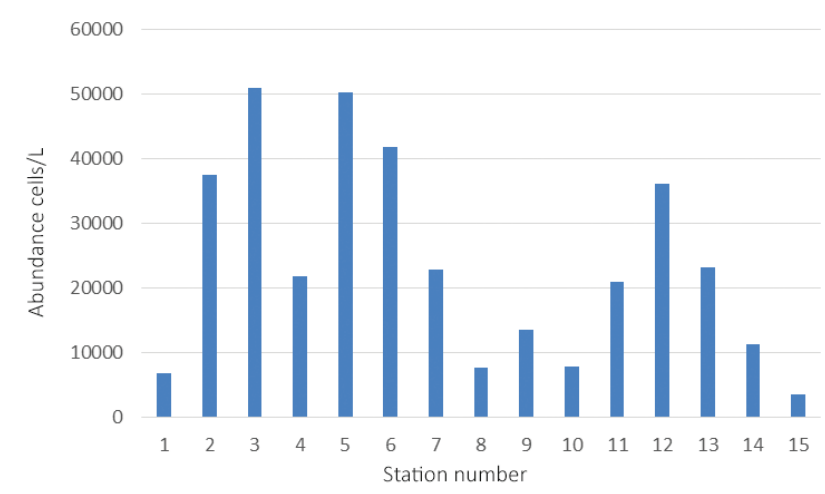

Fig. 3. Abundance of phytoplankton in Lake Kenozero (June, 2018)

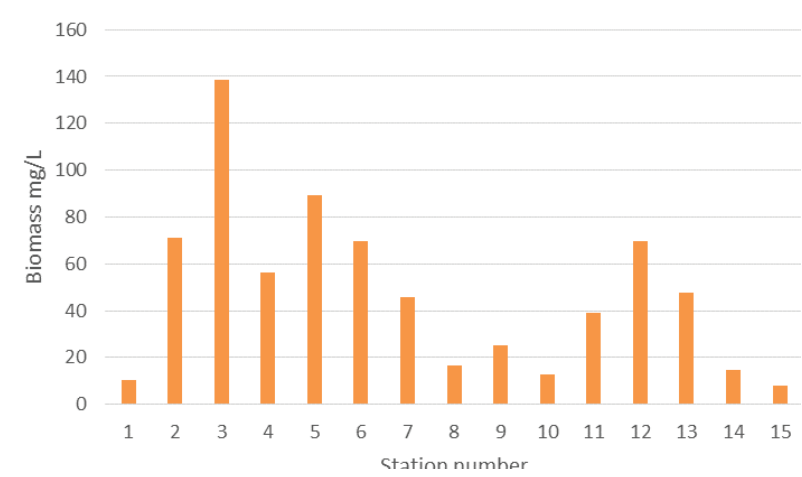

Fig. 4. Biomass of phytoplankton in Lake Kenozero (June, 2018) 
Table 2. Saprobity index according to V. Sladechek. Shannon-Weaver diversity index by abundance and by biomass

\begin{tabular}{|c|c|c|c|}
\hline Station number & $\mathrm{S}$ & $\mathbf{H}_{1}^{\prime}$ & $\mathbf{H}_{2}^{\prime}$ \\
\hline 1 & 1.805 & 3.16 & 3.088 \\
\hline 2 & 1.715 & 3.086 & 2.745 \\
\hline 3 & 1.541 & 1.933 & 1.945 \\
\hline 4 & 1.63 & 3.554 & 3.402 \\
\hline 5 & 1.679 & 3.379 & 3.152 \\
\hline 6 & 1.564 & 3.232 & 3.526 \\
\hline 7 & 1.648 & 3.335 & 3.167 \\
\hline 8 & 1.57 & 2.402 & 2.704 \\
\hline 9 & 1.691 & 2.318 & 2.354 \\
\hline 10 & 1.603 & 2.013 & 2.043 \\
\hline 11 & 1.64 & 3.435 & 3.26 \\
\hline 12 & 1.626 & 3.573 & 3.19 \\
\hline 13 & 1.569 & 2.349 & 2.17 \\
\hline 14 & 1.567 & 2.063 & 1.929 \\
\hline 15 & 1.594 & 3.194 & 2.84 \\
\hline Average value & 1.629 & 2.868 & 2.768 \\
\hline
\end{tabular}

$\mathrm{S}$ - values of saprobity index according to $\mathrm{V}$. Sladechek, $\mathrm{H}_{1}^{\prime}$ - values of Shannon-Weaver diversity index by abundance, $\mathrm{H}_{2}^{\prime}$ - values of Shannon-Weaver diversity index by biomass.

\section{References}

- Abakumov VA (1992) Guidelines for Hydrobiological Monitoring of Freshwater Ecosystems. Gidrometeoizdat, St. Petersburg, 318 pp.

- Barinova SS, Medvedeva LA, Anisimova OV (2006) Biodiversity of Algal Indicators in Environmental Assessment. 498 pp.

- Dvoryankin GA (2016) Fishes of the Kenozersky National Park. Ministry of Natural Resources and Environment of the Russian Federation, Kenozersky National Park, Arkhangelsk, 100 pp.

- Frank NA (1988) Study of the Phytoplankton Distribution Using Optical Methods. Nauka (Siberian Branch), Novosibirsk, $108 \mathrm{pp}$.

- Gollerbakh MM, Polyansky VI (1953) Identification Guide for Freshwater Algae of the USSR. Vol. 2. Sov. Science Publ., Moscow, $652 \mathrm{pp}$.

- Komarenko LE, Vasilyeva II (1975) Freshwater Diatoms and Blue-green Algae of the Water Bodies of Yakutia. Nauka, Moscow, 423 pp.

- Komulaynen SF, Chekryzheva TA, Vislyanskaya IG (2006) Algal Flora of Lakes and Rivers of Karelia - Taxonomic Composition and Ecology. Karelian Research Centre of RAS, Petrozavodsk, $81 \mathrm{pp}$.

- Krishtovich AN (1949a) Diatom Analysis. Vol. 2, Geol. lit. Publ., Moscow, 435 pp.

\section{Conclusion}

The obtained data show that the dominant phytoplankton complex of Kenozero in June 2018 was represented by diatoms (Melosira granulata, Fragilaria crotonensis, Tabellaria fenestrata, Asterionella Formosa), by dinoflagellates (Gymnodinium sp, Protoperidinium bipes), green algae (Closterium acutum) and, zonally, by small small euglenoids. Quantitative indicators of phytoplankton were extremely low. In addition, the values of species diversity indices were also modest.

Therefore, Lake Kenozero belongs to floristically depleted oligotrophic water bodies with a significant predominance of diatoms and low quantitative indicators (abundance and biomass). A slight zonal pollution of the water body by organic wastewater can be assumed. In order to identify the vegetation peaks in the development of phytoplankton community in Kenozero, to collect more information on its species composition and quantitative indicators, as well as to monitor the ecological state of the lake, extensive year-round research is required.

Krishtovich AN (1949b) Diatom Analysis. Vol. 3, Geol. lit. Publ., Moscow, 594 pp.

- Kursanov LI (1953) Identification Guide for Lower Plants. Vol. 2, Sov. Science Publ., Moscow, 312 pp.

- Mikheeva TM (1999) Algal Flora of Belarus: A Taxonomic Catalogue. Minsk, 304-343.

- RD 52.24.309-2016 (2016) Regulatory Document. Organisation and implementation of monitoring observations of the state and pollution of surface waters.

- Shitikov VK, Rosenberg GS, Zinchenko TD (2003) Quantitative Hydroecology: Methods for System Identification. Institute of Ecology of the Volga River Basin, RAS, Tolyatti, 463 pp.

- Unified methods for the study of water quality (1977a) Methods for Biological Analysis of Water. Annex 1 Saprobity indicators. Moscow, $91 \mathrm{pp}$.

- Unified methods for the study of water quality (1977b) Methods for Biological Analysis of Water. Annex 2. Atlas of saprobes. Moscow, 227 pp.

- Zmetnaya MI, Novikova YuV (2015) Current state of the phytoplankton community and surface water quality in the delta of Northern Dvina. Vestnik of Northern (Arctic) Federal University, Arkhangelsk, 44-55. https://doi.org/10.17238/ issn2227-6572.2015.4.44 